\title{
Dynamic stability of phenotypic variation in Polistes wasps (Hymenoptera: Vespidae)
}

\author{
Аинамическая стабильность фенооблика ос рода Polistes \\ (Hymenoptera: Vespidae)
}

\author{
L.Y. Rusina ${ }^{1}$, A.V. Gilyov ${ }^{2}$, L.A Firman ${ }^{1}$, I.A. Pekanova ${ }^{3}$, E.S. Orlova ${ }^{1}$ \\ А.Ю. Русина ${ }^{1}$, А.В. Гимев ${ }^{2}$, А.А. Фирман ${ }^{1}$, И.А. Пеканова ${ }^{3}$, Е.С. Орлова ${ }^{1}$ \\ ${ }^{1}$ Kherson State University, Kherson, Ukraine. E-mail: lirusina@yandex.ru \\ ${ }^{2}$ Institute of Plant and Animal Ecology, Ural Branch of the Russian Academy of Sciences, Ekaterinburg, Russia. \\ ${ }^{3}$ Ural State University, Ekaterinburg, Russia. \\ ${ }^{1}$ Херсонский государственный университет, Херсон, Украина. \\ ${ }^{2}$ Институт экологии растений и животных УрО РАН, Екатеринбург, Россия. \\ ${ }^{3}$ Уральский государственный университет, Екатеринбург, Россия.
}

KEY WORDS: Polistes dominula, Polistes gallicus, Polistes nimpha, chronological variation, melanine pattern polymorphism, population, colony, Black Sea Biosphere Reserve, Trans-Urals.

КЛЮЧЕВЫЕ СЛОВА: Polistes dominula, Polistes gallicus, Polistes nimpha, хронографическая изменчивость, полиморфизм меланиновых рисунков, популяция, семья, Черноморский биосферный заповедник, Зауралье.

ABSTRACT. The present paper analyzes chronological variation of melanine patterns in Polistes dominula (Christ) and P. gallicus (Linnaeus) wasps in the Black Sea Biosphere Reserve in the Kherson Region (Ukraine) in 2003-2006, and that of P. nimpha (Christ) in the Kherson Region and in the Trans-Urals (the Kurgan Region, Russia) in 2006-2008. We have examined variation of coloration patterns of the clypeus, mesoscutum, and first metasomal tergite in 4426, 1804, and 559 foundresses and future foundresses of $P$. dominula, $P$. gallicus and $P$. nimpha respectively. Seasonal changes in the phenotypic variation within populations were more obvious during certain years. Due to mainly cyclic nature of those changes, the examined populations retained their general phenotypic traits. Variation patterns of that kind are likely to be created by certain types of selection.

РЕЗЮМЕ. В настоящей работе дан анализ хронографической изменчивости меланинового рисунка у ос Polistes dominula (Christ) и P. gallicus (Linnaeus) в Черноморском биосферном заповеднике Херсонской области (Украина) в 2003-2006 гг., а также у $P$. nimpha (Christ) в Херсонской области и в Зауралье (Курганская область, Россия) в 2006-2008 гг. У 4426, 1804 и 559 самок-основательниц и будущих основательниц, принадлежащих соответственно к $P$. dominula, $P$. gallicus и $P$. nimpha, рассмотрены варианты рисунка клипеуса, мезоскутума и первого тергита метасомы. Сезонные изменения фенооблика популяций были более сильно выражены в отдельные годы. Благодаря преимуществен- но циклическому характеру этих изменений, популяция в целом сохраняла стабильность по указанным признакам. Обсуждена возможность появления подобной картины изменчивости в результате действия некоторых форм отбора.

\section{Introduction}

Alternative phenotypes are of special interest for evolutionary studies. M.J. West-Eberhard [1986, 2003] refers the term "alternative phenotypes" to "alternatives of all kinds... whether reversibly or irreversibly determined and whether regulated primarily by genotypic or environment factors" [West-Eberhard, 2003] (p. 378). Various kinds of alternative phenotypes, i.e. polymorphisms, polyphenisms as well as alternative behavioral, physiological and life-history traits, are dynamic adaptations of the population, finely adjusting it to certain environmental changes [Waddington, 1964; Mayr, 1968; Timofeev-Resovsky et al., 1973; WestEberhard, 1986; Shishkin, 1986, 1988; Yablokov, Yusufov, 1989; Rasnitsyn, 2002; Vasilyev, 2005]. The classic examples of polymorphism of that kind include the well-known industrial melanism of the British peppered moth, Biston betularia (Linnaeus, 1758) (Lepidoptera: Geometridae), cyclic fluctuations of the black and red morphs in the two-spotted ladybird, Adalia bipunctata (Linnaeus, 1758) (Coleoptera: Coccinellidae) [Timofeev-Resovsky et al., 1969; Sergievsky, 1985], dynamics of the color and size patterns of shell bands in Cepaea nemoralis (Linnaeus, 1758) and in other molluscs [Sergievsky, 1985, 1987]. Examples 
similar to those described above are relatively scarce, and therefore all detected cases of temporal and spatial change of frequencies of different morphs are of significant theoretical interest.

Wasps of the genus Polistes Latreille, 1802 are a good model for studying alternative phenotypes in social insects. They can be effectively studied due to small size of their colonies, open-type nests, and low level of aggression. Relatively large individuals with the contrasting melanine patterns facilitate classification of different morphs, individual marking of the wasps, and description of life cycles at the both individual and colony level throughout the season [Rusina, 2009]. During the present study, we have examined dynamic changes of frequencies of color patterns in several Polistes species at a few selected sites over a number of years.

This paper is dedicated to Prof. Alexandr Pavlovich Rasnitsyn on his 75th anniversary.

\section{Materials and methods}

Individuals of Polistes dominula (Christ, 1791) and $P$. gallicus (Linnaeus, 1767) were collected at the IvanoRybalche $\left(46^{\circ} 45^{\prime} \mathrm{N}, 32^{\circ} 18^{\prime} \mathrm{E}\right)$ and Solenoozerniy $\left(46^{\circ} 46^{\prime} \mathrm{N}, 31^{\circ} 99^{\prime} \mathrm{E}\right)$ plots of the Black Sea Biosphere Reserve (BSBR) (the Kherson Region, Ukraine), and those of $P$. nimpha (Christ, 1791) - at various residential localities in the Kherson Region (Ivano-Rybalche plot of BSBR, Vinogradnoe village $\left(46^{\circ} 49^{\prime} \mathrm{N}, 32^{\circ} 17^{\prime}\right.$ E) in the Goloprystanskiy District, Muzykovka village $\left(46^{\circ} 75^{\prime} \mathrm{N}, 32^{\circ} 56^{\prime} \mathrm{E}\right)$ in the Belozersky District), and

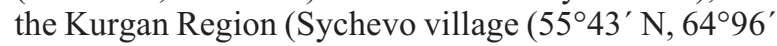
E) in the Ketovskiy District).

During our studies, the colonies were examined for a number of years in the middle of May. The examination included collecting of foundresses, description of the variants of melanine patterns of their clypeus, mesosoma (functional thorax) and metasoma (functional abdomen) according to the existing classification $[\mathrm{Ru}-$ sina, 2009], and marking of individuals by putting plastic rings on their pedicels. At the end of May, nests with foundresses were transferred from the open air into plastic containers with a removable bottom to protect the colonies from predators. The nests were examined every two or three days, and the presence of foundresses as well as survival and brood development were recorded. The description of phenotypic variation and marking of new individuals was done in the laboratory where the colonies were taken overnight. Future foundresses were distinguished from workers according to the specificity of the seasonal development of the colony, i.e. future foundresses usually appear after the mass emergence of the males.

Changes in phenotypic variation of $P$. dominula (2003-2006, $\mathrm{N}=3698$ ) and $P$. gallicus foundresses (2004-2006, $\mathrm{N}=1804$ ) at the Ivano-Rybalche plot of BSBR were analyzed by comparing the variants of melanine patterns of: (1) foundresses after hibernation that started to found nests in spring, (2) foundresses by the time of worker emergence, (3) foundresses by the time of emergence of reproductive individuals, and (4) future foundresses. P. dominula colonies on the Solenoozerniy plot of BSBR (2008-2010, $\mathrm{N}=728)$ and $P$. nimpha colonies of the Kherson (2003-2004, $\mathrm{N}=$ 387 ) and Kurgan Regions (2006-2008, $N=172$ ) were the objects for comparing the phenotypic variation in the spring foundresses and future ones.

We have examined color patterns in 6789 wasps. The comparison of phenotypic variation at different stages of the foundresses' life cycle was done using Cavalli-Sforza distance as the most indicative measure [Zhivotovsky, 1991]. The generalized distance between samples was calculated as an arithmetic mean of distances by separate traits. To visualize phenotypic paths of wasp populations over a number of seasons, the obtained matrices of phenotypic distances were analyzed using multivariate scaling. Statistical significance of differences was estimated with the help of the $\chi^{2}$ test. All calculations were done using the software package STATISTICA version 6.0 (Statsoft Inc., USA).

\section{Results}

The phenotypic composition of foundresses of different Polistes species does not remain stable during a number of years and different stages of life cycle of the wasps.

Figs $1 \mathrm{~A}$ and $\mathrm{B}$ show phenotypic paths of $P$. dominula and $P$. gallicus settlements at the Ivano-Rybalche plot of BSBR. Both species demonstrate virtually similar patterns which can be characterized as the "dynamic stability of phenotypic variation". Future foundresses appear to be the most similar to each other, showing stable phenotypic variation for a number of years.

Overwintered nest-initiating foundresses are notably different both from the future ones appeared during the previous season and from each other as well. The phenotypic variation therefore shifts every year in a different direction. Apparently, the conditions of overwintering and perhaps also those of dispersal of the future foundresses are quite different, which leads, in turn, to multidirectional phenotypic shifts due to a nonrandom selective elimination of certain foundresses. Further changes in the phenotypic variation of the settlement in the spring and summer occur through more or less random elimination of some foundresses by predators. At the same time, we also observed significant differences between the studied species.

For example, foundresses that emerge after hibernation are phenotypically quite close to the future ones in $P$. dominula. Nevertheless, considerable shifts in the frequencies of the melanine pattern do not occur. This was especially true for the seasons of 2004-2005, although after the severe winter of 2006 and especially after that of 2003 the changes were more obvious. Subsequent stages of the life cycle display further shifts in phenotypic variation that proceed in the same direc- 


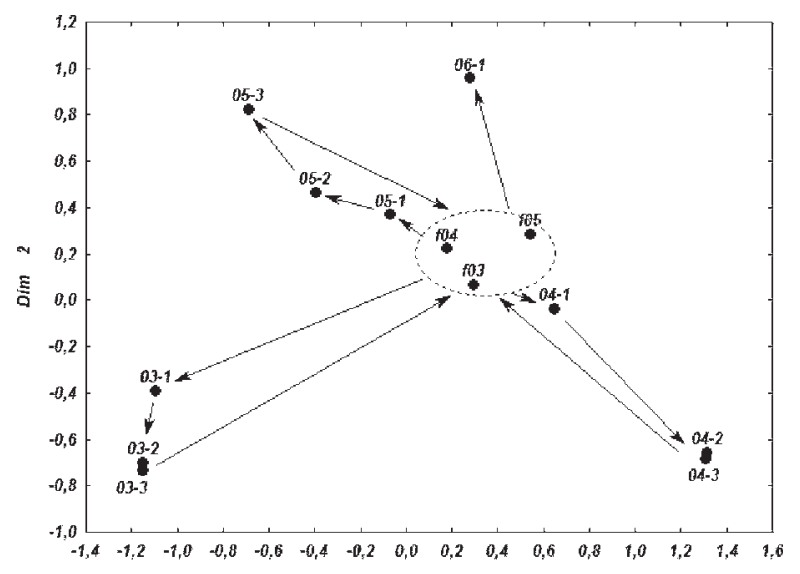

A

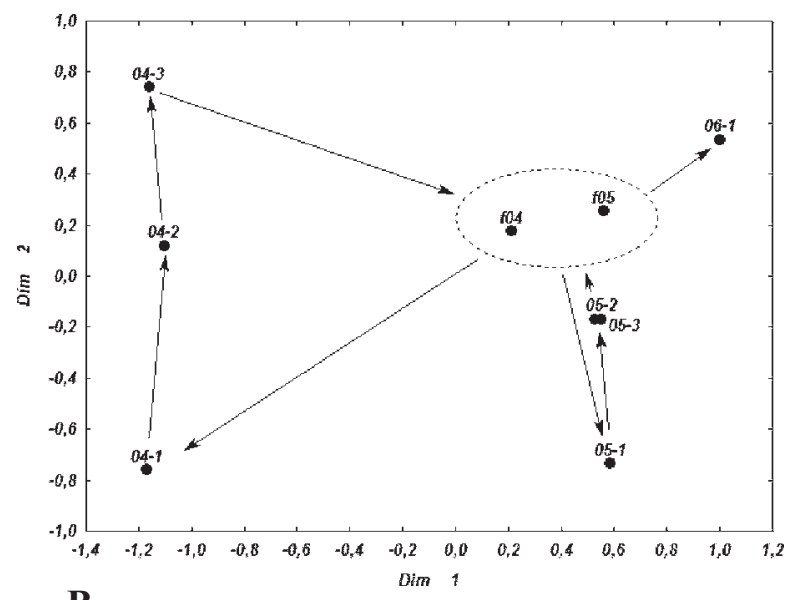

B

Fig. 1. Phenotypic paths of the settlements of $P$. dominula (A) and P. gallicus (B) at the Ivano-Rybalche plot of the Black Sea Biosphere Reserve (BSBR) in 2003-2006 and 2004-2006. 03-1, 04-1, 05-1, 06-1 - melanine patterns of the overwintered nesting foundresses; 03-2, 04-2, 05-2 - melanine patterns of the foundresses by the time of the emergence of workers; 03-3, 04-3, 05-3 melanine patterns of the foundresses by the time of the emergence of the reproductive generation; f03, f04, f05 - melanine patterns of the future foundresses.

Рис. 1. Фенотипические траектории поселений (А) $P$. dominula и (B) P. gallicus Ивано-Рыбальчанского участка Черноморского биосферного заповедника (ЧБ3) в 2003-2006 гг. и 2004-2006 гг. 03-1, 04-1, 05-1, 06-1 — варианты рисунков основательниц, гнездящихся после зимовки; 03-2, 04-2, 05-2 варианты рисунков основательниц к выходу рабочих; 03-3, 043, 05-3 - варианты рисунков основательниц к выходу репродуктивного поколения; f03, f04, f05 - варианты рисунков будущих основательниц.

tion, and the wasp population therefore moves away from its initial state.

However, the strongest phenotypic shifts are observed after hibernation in P. gallicus, when spring foundresses differ most substantially from the future ones. Later on, the settlement gradually returns to its initial state, and the reproductive females become similar to the future foundresses. To summarize, the natural selection operates through the differential survival

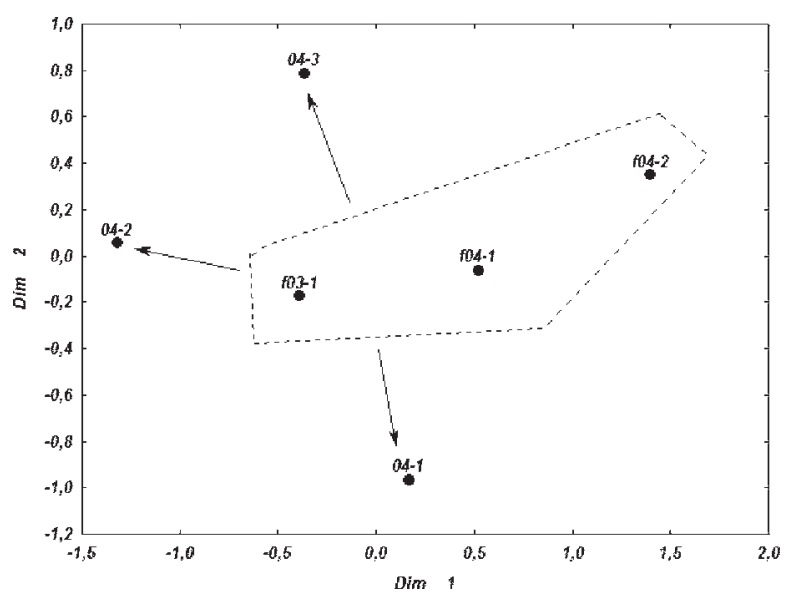

Fig. 2. Phenotypic paths of $P$. nimpha from the Kherson Region in 2003-2004. f03-1 - melanine patterns of the future foundresses in Vinogradnoe village; 04-1, f04-1 - melanine patterns of the overwintered nesting foundresses and the future ones in Vinogradnoe village; 04-2, f04-2 - melanine patterns of the overwintered nesting foundresses and the future ones at the IvanoRybalche plot of BSBR; 04-3 - melanine patterns of the overwintered nesting foundresses in Muzykovka village.

Рис. 2. Фенотипические траектории поселений $P$. nimpha в Херсонской обл. в 2003-2004 гг. f03-1 - варианты рисунков будущих основательниц в с. Виноградное; 04-1, f04-1 - варианты рисунков основательниц, гнездящихся весной, и будущих основательниц в с. Виноградное; 04-2, f04-2 - варианты рисунков основательниц, гнездящихся весной, и будущих основательниц на Ивано-Рыбальчанском участке ЧБЗ; 04-3 варианты рисунков основательниц, гнездящихся весной, в с. Музыковка.

of foundresses during hibernation as well as through differential reproduction in summer. However, despite these shifts, the generation of future foundresses of both species eventually returns to the initial pattern of phenotypic variation, and therefore there is no evidence for the appearance of new variants in the populations. Despite the scarcity of data, the analysis of spatial distribution of $P$. nimpha from the Kherson Region also confirms the hypothesis of similarity of the phenotypic variation of future foundresses from different habitats. Fig. 2 clearly demonstrates that characteristics of the future foundresses from three different localities and a few distinct habitats can be seen in the middle of the diagram (enclosed with the dashed line), whereas all spring foundresses occupy the peripheral position.

In the population of P. nimpha in the Trans-Urals, foundresses are phenotypically similar (Figs 3A and $\mathrm{B})$. In contrast to that, future foundresses are morphologically distant from each other. However, melanine patterns of the clypeus that are monomorphic in foundresses and include additional rare variants in the future ones, can contribute significantly to this variation. The pattern dramatically changes if this information is neglected (Fig. 3B). Foundresses cluster together, whereas the future ones form another phenotypic cluster. In this case, phenotypic variation fluctuates within a certain range, especially along the first axis, also demonstrating its dynamic stability. 


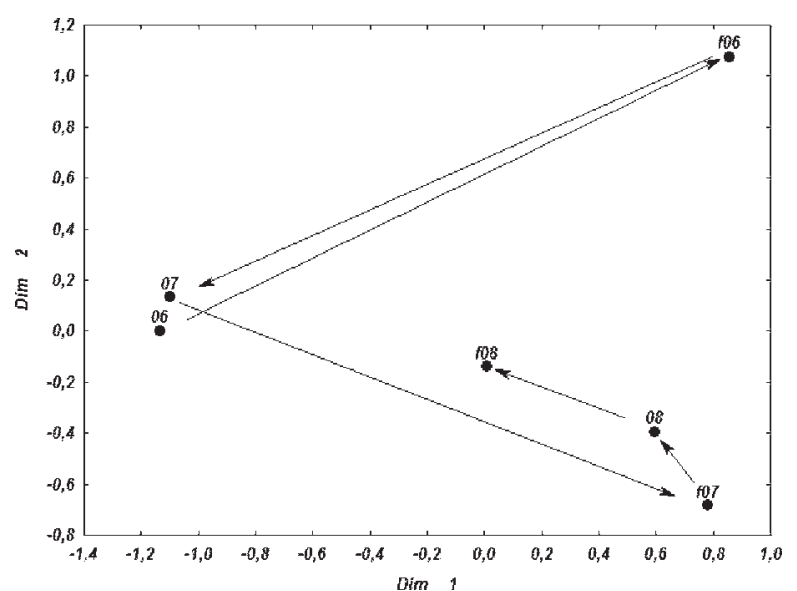

A

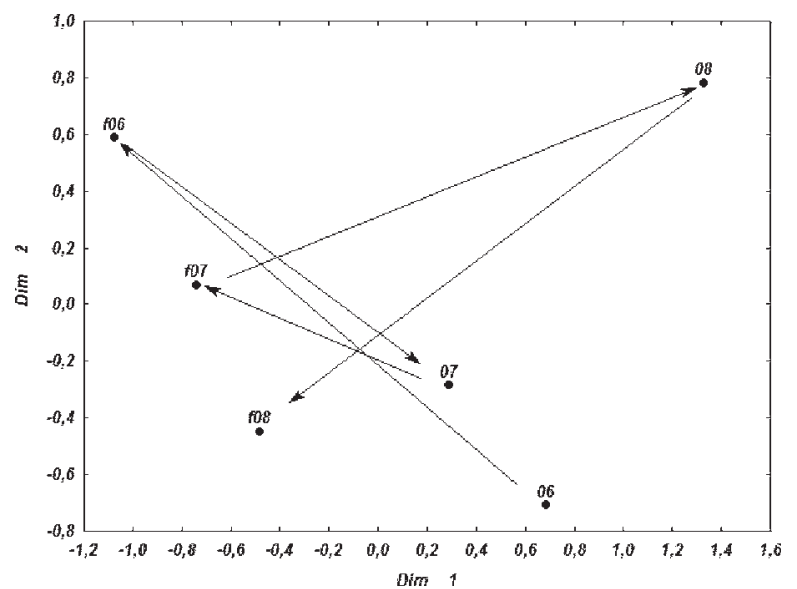

B

Fig. 3. Phenotypic paths of $P$. nimpha population in the TransUrals in 2006-2008. A - frequencies of melanine patterns of the clypeus, B - frequencies of melanine patterns of the mesoscutum. 06, 07, 08 - melanine patterns of the overwintered nesting foundresses; f06, f07, f08 - melanine patterns of the future foundresses.

Рис. 3. Фенотипические траектории популяции P. nimpha в Зауралье в 2006-2008 гг. А - частоты вариантов рисунка клипеуса, В - частоты вариантов рисунка мезоскутума. 06, 07, 08 - варианты рисунков основательниц, гнездящихся весной; f06, f07, f08 - варианты рисунков будущих основательниц.

An analogous pattern can be seen in $P$. dominula at the Solenoozerniy plot of BSBR. Foundresses of this species are more phenotypically similar to each other than the future ones (Fig. 4A). As in the population from the Trans-Urals, melanine patterns of the clypeus mainly contribute to this similarity (Fig. 4B). Foundresses form a very compact cluster based on the melanine

Рис. 4. Фенотипические траектории поселений $P$. dominula Соленоозерного участка ЧБЗ в 2008-2010 гг. А — частоты фенотипов самок-основательниц; В - частоты вариантов рисунка клипеуса; C - частоты вариантов рисунка мезоскутума 08, 09, 10 - варианты рисунков основательниц, гнездящихся весной; f08, f09, f10 — варианты рисунков будущих основательниц.

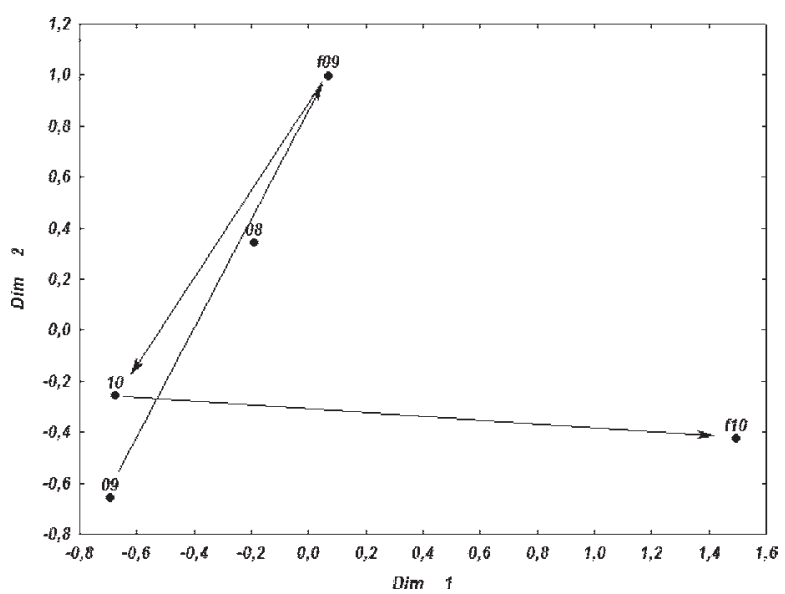

A

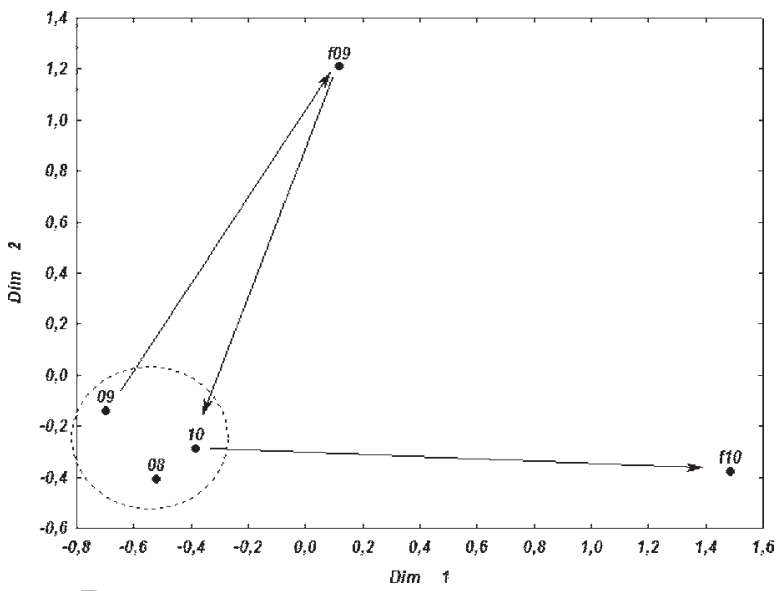

B

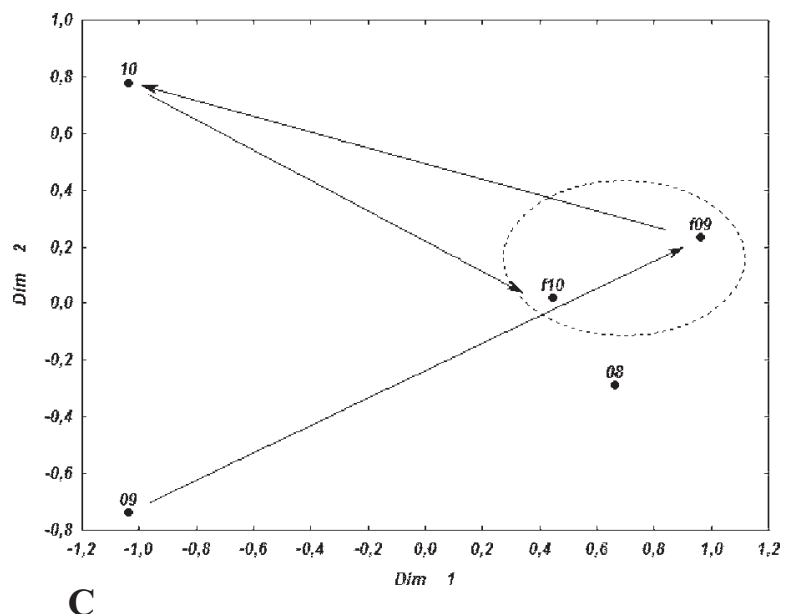

Fig. 4. Phenotypic paths of $P$. dominula settlements at the Solenoozerniy plot of BSBR in 2008-2010. A - frequencies of the foundresses' phenotypes; B - frequencies of melanine patterns of the clypeus; $\mathrm{C}-$ frequencies of melanine patterns of the mesoscutum. 08, 09, 10 - melanine patterns of the overwintered nesting foundresses; f08, f09, f10 - melanine patterns of the future foundresses. 
patterns of the clypeus, while the future ones strongly differ from each other due to rare phenotypic variants.

Nevertheless, future foundresses show very similar phenotypic variation of their melanine patterns of the mesoscutum, whereas the foundresses appear to be significantly different (Fig. 4C). However, this settlement also recurrently returns to its original pattern of phenotypic variation, and the same is true for $P$. dominula collected at the Ivano-Rybalche plot. Populations of the both species, i.e. that of $P$. nimpha in the Trans-Urals and the population of $P$. dominula at the Solenoozerniy plot, therefore display relatively independent dynamics of various features of melanine patterns of different parts of the body.

\section{Discussion}

The temporal stability of the phenotypic variation, including stable polymorphism involving alternative phenotypes is currently considered as a consequence of a long process of adaptation of the population to the specific environment [Novozhenov, 1978, 1989; Vasilyev, 2005]. The population is in the dynamic balance with the environment, i.e. it is adapted to a certain range of environmental fluctuations typical for a given area [Timofeev-Resovsky et al., 1973; Yablokov, 1987]. However, specific pathways of adaptation in closely related species (e.g. in those discussed here) can differ substantially.

The specificity of social systems of Polistes species has something to do with their tendency for colony foundation and nest rebuilding in groups [Reeve, 1991; Rusina, 2006]. Haplometrosis is typical for P. gallicus, while in $P$. dominula as well as in $P$. nimpha both haplo- and pleometrosis are observed. The extent of pleometrosis is subject to spatial and temporal variation. Pleometrotic colonies are better protected from invertebrate predators and successfully rebuild their nests in case of destruction [Reeve, 1991].

The period from nest foundation to worker emergence is the most vulnerable in the life cycle of Polistes, since up to $80 \%$ of the population dies from predators and other mortality factors. After destruction of the first nest, foundresses rebuild it or join alien colonies [Reeve, 1991]. In P. gallicus, secondary nests account for more than one-third of the population [Rusina, Grechka, 1993; Rusina, 2009]. In P. dominula, the foundresses usually join a conspecific colony, whereas successful nest rebuilding is observed more rarely. $P$. nimpha are similar in that respect to $P$. gallicus, although joining alien colonies (usurpation) also occurs at times.

It is noteworthy that the mating frequency also significantly varies between foundresses of different species. Specifically, foundresses of $P$. gallicus mate only once [Strassmann et al., 2003], whereas, according to our data, more than $15 \%$ foundresses $P$. dominula and $P$. nimpha mate twice. All those differences can affect the phenotypic variation within populations.
In the populations of $P$. dominula from Southern Ukraine, an adaptive response to environmental changes results in the emergence of phenotypically diverse offspring in the colonies with different structure. For instance, small foundresses with darker melanine patterns emerge more often in the colonies with the higher conflict levels, i.e. either under pleometrosis, or within colonies with egg-laying workers and in the usurped nests, as well as in colonies infested by parasitoids and in the secondary nests. In those colonies, development of individuals is disturbed at the larval stage, which apparently leads to significant changes in characteristics of their subsequent melanine patterns and behavior.

The phenomenon of the restoration of the phenotypic variation in a new generation of foundresses that usually occurs during the autumn, can be explained by genetic effects underlying normal reactions of the population as well as by certain environmental factors, like specific larval diet. Air temperatures in August can also influence the emergence of future foundresses. In the latter case, environmental factors during this vulnerable period are likely to be quite constant over a number of years, which results in the observed phenotypic stability of the population.

In the populations inhabiting the northern border of their species distribution range, i.e. in those of $P$. gallicus in the Kherson Region and of P. nimpha in the Trans-Urals, adaptation takes place through selection for the emergence of highly productive foundresses. In such habitats, certain abiotic factors, such as conditions of overwintering or periods of drought, together with predators and parasitoids can play the role of "pacemakers" of the dynamics of phenotypic variation. Judging from the dramatic phenotypic shifts, populations of those species appear to be more sensitive to environmental fluctuations. In P. gallicus, environmental conditions during the period of the emergence of future foundresses is also constant, thus providing stability of the phenotypic variation. For $P$. nimpha in the Trans-Urals, we can see a certain trend in the dynamics of phenotypic variation in future foundresses, which suggests a more unstable environment.

In conclusion, we would like to point out that further studies of the complex underlying mechanisms of population polymorphism in Polistes species will allow better understanding of various aspects of their life histories.

\section{References}

Mayr E. 1968. [Zoological species and evolution]. Moscow: Mir. 597 pp. [in Russian].

Novozhenov Yu.I. 1978. [Phenogeography of the stable polymorphism] // Fisiologicheskaya i populyatsionnaya ekologiya zhivotnykh. Saratov. Vol.5. No.7. P.41-47 [in Russian].

Novozhenov Yu.I. 1989. [Chronographic variation in the population] // Zhurnal Obshchei Biologii. Vol.50. No.2. P.171-183 [in Russian, with English summary].

Rasnitsyn A.P. 2002. [The process of evolution and methodology of systematics] // Proceedings of the Russian Entomological 
Society. Vol.73. 107 pp. [in Russian, with English summary]. Reeve H.K. 1991. Polistes // Ross K.G., Matthews R.W. (eds). The Social Biology of Wasps. New York: Cornell University Press. P.99-148.

Rusina L.Y. 2006. [Polistine wasps in the natural and anthropogenic landscapes of the Lower Dnieper Area]. Kherson: Kherson State University Publishers. 200 pp. [in Russian].

Rusina L.Y. 2009. [Structure and functional organization of populations of Polistes wasps (Hymenoptera, Vespidae)] // Proceedings of the Russian Entomological Society. Vol.79. 217 pp. [in Russian, with English summary].

Rusina L.Yu., Grechka E.O. 1993. [Life cycle of Polistes chinensis wasps in the Kherson Region] // Proceedings of the Colloquium on Social Insects. St. Petersburg. P.157-167 [in Russian, with English summary].

Sergievsky S.O. 1985. [Multifunctionality and plasticity of genetic polymorphism (using population melanism in the two-spotted ladybird Adalia bipunctata (L.) as an example] // Zhurna Obshchei Biologii. Vol.46. No.4. P.491-502 [in Russian, with English summary].

Sergievsky S.O. 1987. [Polymorphism as a universal adaptive strategy of populations] // Trudy Zoologicheskogo Instituta AN SSSR. Vol.160. P.41-58 [in Russian].

Shishkin M.A. 1986. [Epigenetic system as an object of the selective transformation] // Morphologiya i evolutsiya zhivotnykh. Moscow: Nauka. P.63-73 [in Russian].

Shishkin M.A. 1988. [Evolution as an epigenetic process] // Sovremennaya paleontologiya. Vol.2. No.7. Obshchie zakonomer- nosti evolutsii organicheskogo mira. Moscow: Nedra. P.142168 [in Russian].

Strassmann J.E., Nguyen J.S., Arevalo E., Cervo R., Zacchi F., Turillazzi S., Queller D.C. 2003. Worker interests and male production in Polistes gallicus, a Mediterranean social wasp // Journal of Evolutionary Biology. Vol.16. P.254-259.

Timofeev-Resovsky N.V., Vorontsov N.N., Yablokov A.V. 1969. [A short essay on evolutionary theory]. Moscow: Nauka. 408 pp. [in Russian].

Timofeev-Resovsky N.V., Yablokov A.V., Glotov N.V. 1973. [Essay on population studies]. Moscow: Nauka. 278 pp. [in Russian].

Vasilyev A.G. 2005. [Epigenetic basis of phenetics: on the way to population meronomy]. Ekaterinburg: Akademkniga. 640 pp. [in Russian].

Waddington C.H. 1964. [Morphogenesis and genetics]. Moscow: Mir. 267 pp. [in Russian].

West-Eberhard M.J. 1986. Alternative adaptations, speciation and phylogeny (a review) // Proceedings of the National Academy of Sciences of the USA. Vol.83. P.1388-1392.

West-Eberhard M.J. 2003. Developmental plasticity and evolution. Oxford: Oxford University Press. 816 pp.

Yablokov A.V. 1987. [Population biology]. Moscow: Vysshaya Shkola. 303 pp. [in Russian].

Yablokov A.V., Yusufov A.G. 1989. [Evolutionary theory]. Moscow: Vysshaya Shkola. 336 pp. [in Russian].

Zhivotovsky L.A. 1991. [Population biometrics]. Moscow: Nauka. 271 pp. [in Russian] 